\title{
Pituitary apoplexy and panhypopituitarism following acute leptospirosis
}

\author{
Jaypalsinh Gohil ${ }^{1} \cdot$ Arun Gowda $^{1} \cdot$ Tobin George $^{1} \cdot$ H. V. Easwer ${ }^{1} \cdot$ Alexander George $^{2} \cdot$ Prakash Nair $^{1}$ (I)
}

Accepted: 12 May 2021 / Published online: 21 May 2021

(c) The Author(s), under exclusive licence to Springer Science+Business Media, LLC, part of Springer Nature 2021

\begin{abstract}
Leptospirosis is a common tropical febrile illness which may manifest with the hepatorenal syndrome and systemic hemorrhagic manifestations. Pituitary apoplexy is a rare but life-threatening condition characterized by a hemorrhage within the pituitary gland or a pituitary adenoma. Apoplexy is very rarely associated with some inducing events such as infectious diseases such as dengue hemorrhagic fever, Hantaan virus, Puumala virus have also been reported to cause pituitary apoplexy. We present the first case of pituitary apoplexy in a patient who was being treated for leptospirosis and discuss the possible mechanisms of apoplexy in the scenario presented. We also review other reports of infectious causes that may result in pituitary apoplexy.
\end{abstract}

Keywords Pituitary adenoma $\cdot$ Leptospirosis infection $\cdot$ Pituitary apoplexy $\cdot$ Spontaneous adenoma resolution

\section{Introduction}

Pituitary apoplexy is a rare but life-threatening condition characterized by a hemorrhage within the pituitary gland or a pituitary adenoma. Infectious diseases such as dengue hemorrhagic fever, Hantaan virus, Puumala virus have been reported to rarely cause pituitary apoplexy. Leptospira Interrogans is the causative organism for leptospirosis, which is a common tropical febrile illness that may manifest with the hepatorenal syndrome and systemic hemorrhagic manifestations. We present the first case of pituitary apoplexy in a patient who was being treated for leptospirosis and discuss the possible mechanisms of apoplexy in the scenario presented. We also review other reports of acute pituitary apoplexy in the setting an acute infectious illness.

Prakash Nair

drprakashnair@gmail.com

1 Sree Chitra Tirunal Institute for Medical Sciences and Technology, Thiruvananthpuram, Kerala, India

2 Holy Cross Hospital, Kottiyam, Kerala, India

\section{Case report}

A 56-year-old male with a medical history of type 2 Diabetes Mellitus was admitted to a general hospital with fever, nausea, vomiting, and abdominal pain for 5 days duration. During hospital evaluation, mild hepatosplenomegaly was noted on abdominal ultrasound. His chest X-ray was unremarkable.Complete blood count (CBC) at the time of admission showed a total white blood cell count (WBC) of $11,700 / \mathrm{microl}$ with $90 \%$ neutrophils and $10 \%$ lymphocytes (shift to left). The erythrocyte sedimentation rate (ESR) was $62 \mathrm{~mm} / \mathrm{hr}$. The serum creatine at admission was $1.8 \mathrm{mg} / \mathrm{dl}$ and blood urea were $56 \mathrm{mg} / \mathrm{dl}$. The platelet count was $245,000 / \mathrm{microl}$. During the serological evaluation for the etiology of a febrile illness, leptospira ELISA IgM was found to be elevated. Serological investigations for other febrile illnesses including dengue, typhoid and paratyphoid were negative. A clinical diagnosis of leptospirosis with acute kidney injury was established and treatment with intravenous cefoperazone and sulbactam along with oral doxycycline was administered. Over the course of the next few days, he became afebrile and maintained adequate urine output, his WBC count decreased to $6300 / \mathrm{microl}$ and his serum creatinine decreased to $1.2 \mathrm{mg} / \mathrm{dl}$. After 5 days of admission he developed sudden onset severe headache, with diplopia, and partial ptosis in the left eye. On neurological evaluation, the left 
pupil was dilated and non-reactive to light. Visual field examination revealed bitemporal hemianopsia. Cerebrospinal fluid (CSF) examination was non-meningitic (CSF Glucose $85 \mathrm{mg} / \mathrm{dl}$, protein $78 \mathrm{mg} / \mathrm{dl}$, cells-nil). Other blood investigations included WBC 6300/microl, platelets 400,000/microl and ESR-103 mm/hr. His blood clotting time at this instance was $10 \mathrm{~min}$ while the bleeding time was $1 \mathrm{~min}$. The estimated Prothrombin time was $13.5 \mathrm{Sec}-$ onds (INR-1). An MRI of the brain showed a sellar mass with hemorrhagic component measuring $1.5 \times 2 \times 2.4 \mathrm{~cm}$ in size expanding the sella and extending into the suprasellar cistern. The mass showed T2W hyper intensity and TIW isointensity with hypo intense areas of "blooming" in SWI sequences, which suggested hemorrhage. Plain CT head also showed hemorrhage in the pituitary adenoma. There was Knosp grade 4 involvement of the left cavernous sinus with more than $180^{\circ}$ encasement left Internal Carotid Artery (ICA) (Fig. 1). The MRI was consistent with apoplexy in a pituitary adenoma. On evaluation of anterior pituitary function showed evidence of hypopituitarism [S Cortisol $0.41 \mathrm{microgm} / \mathrm{dl}$, TSH $0.16 \mathrm{mIU} / \mathrm{L}$, Prolactin $3.21 \mathrm{ng} / \mathrm{ml}$ (1:100 dilution)]. In view of hypocortisolism, replacement doses of glucocorticoids were initiated. His hospital course was complicated by an acute kidney injury from which he made full recovery. He was then referred to our hospital for further management of the pituitary apoplexy where he was seen two weeks after the occurrence of pituitary apoplexy. On examination, the left-sided third nerve palsy had improved. There was only partial left sided ptosis and a full range of extraocular movements were present in the left eye. Repeat visual field charting showed resolution of the prior bitemporal hemianopsia and a full visual field. The right eye examination was normal. Contrast enhanced CT scan of the head performed during this visit revealed that the adenoma has decreased in size, with resolution of the hemorrhage. We then decided to place the patient on imaging follow up. Two months later, he no longer had ptosis in the left eye,
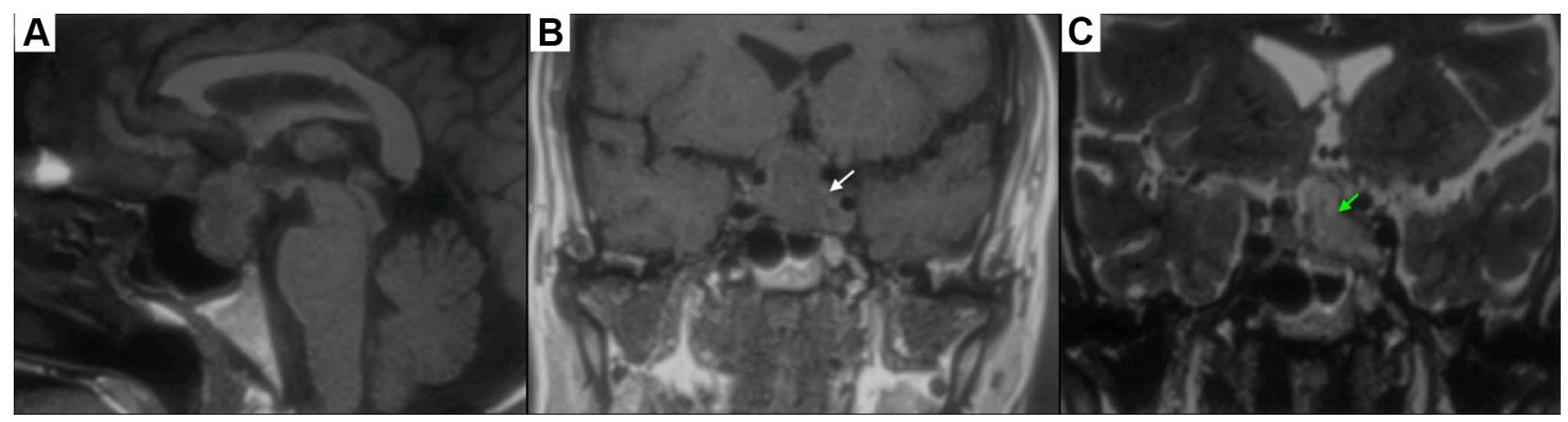

Fig. 1 MRI Brain T1WI (A) sagittal and (B) coronal view showing isointense and (C) T2WI coronal view showing hyperintense, adenoma with left parasellar extension and encasement of left cavernous
Internal Carotid Artery and cavernous sinus involvement. there is evidence of haemorrhage into the left half of the gland (white and green arrow)
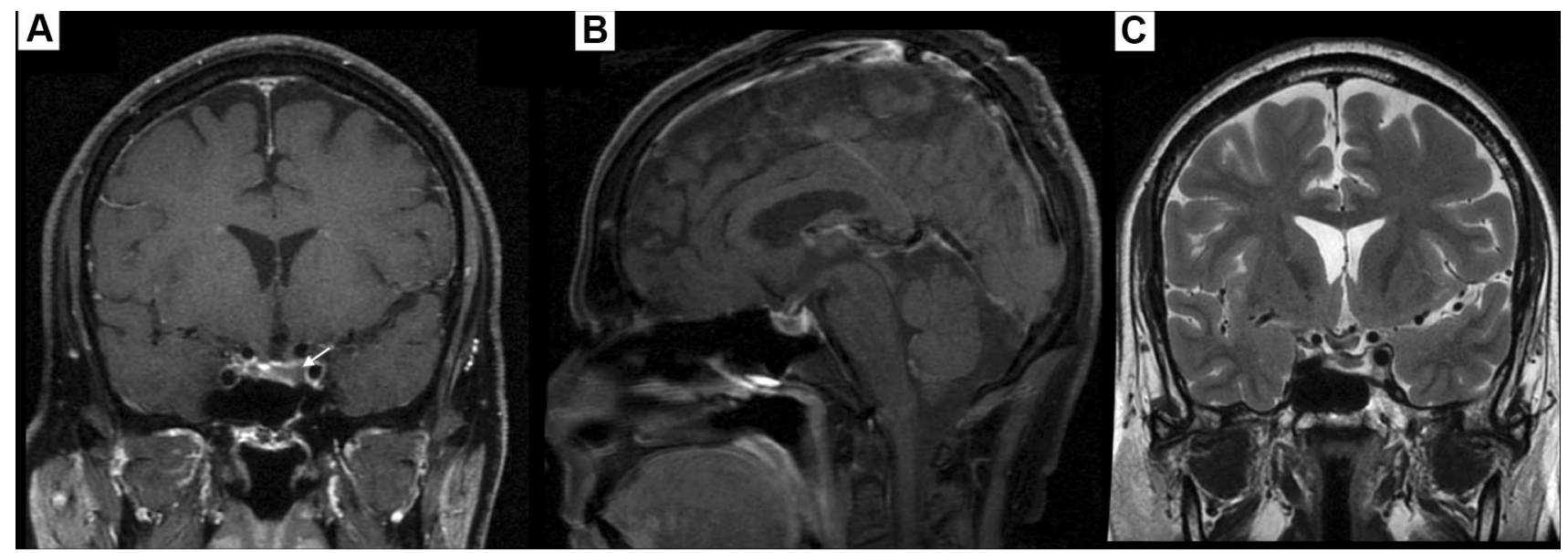

Fig. 2 MRI Brain T1WI post contrast (A) coronal and (B) sagittal view and (C) T2WI coronal view showing small nonenhancing adenoma (arrow) on the left side of sella 
the extra ocular movements were normal, and he had no visual field defects. The MRI performed during this visit showed resolution of the hemorrhagic focus and regression of the pituitary adenoma with a residual $4 \mathrm{~mm}$ adenoma in the left side of the Sella adjacent to the left cavernous ICA (Fig. 2). This residual lesion is being followed up with serial MRI images. He is still on replacement doses of corticosteroid and thyroid hormones and is being monitored for recovery of pituitary function.

\section{Discussion}

Leptospirosis is a zoonotic infectious disease that results in hemorrhagic diathesis, liver dysfunction, and renal failure. The causative organic L. Interrogans is a motile spiralshaped, biflagellate that can burrow into the tissue. Rodents are the most important reservoir of the organism; however, various farm animals and wild animals may also harbor the disease. The organism is excreted in the urine of the infected host [1]. The incidence of leptospirosis in the Indian subcontinent spikes during and soon after the monsoon season, which leads to flooding of agricultural land. Human infection with Leptospira occurs through the skin, which may come in contact with water contaminated with animal urine. Drinking contaminated water may also result in infection through the mucosal surface [2]. In untreated cases, a spirochetemic phase is followed by an immune phase. During this phase of spirochetemia, organisms can be found in the blood, cerebral spinal fluid (CSF), aqueous humor, and most tissues [3]. A more severe manifestation of leptospirosis is the Weil's syndrome characterised by hepatorenal involvement, haemorrhage and septicaemic shock $[4,5]$.

Studies from the subcontinent have also shown that jaundice was one of the most common symptoms of leptospirosis followed by oliguric renal failure. The diagnosis of this disease is based on assessment of clinical features and serological tests mainly the ELISA IgM estimation [3]. When leptospirosis involves the central nervous system it causes headache, nuchal rigidity, photophobia and altered sensorium in addition to other less common manifestations like seizures, delirium, encephalopathy and coma [6]. This case is unique in this regard as Leptospirosis associated with pituitary apoplexy has not yet reported.

Pituitary apoplexy is defined as clinical syndrome due to abrupt hemorrhagic and /or infarction of the pituitary gland, generally within a pituitary adenoma [7] The pituitary gland derives its blood supply from the loose capillary networks forming portal circulation supplied by superior and inferior hypophyseal arteries. A pituitary adenoma on the other hand derives its vascularity from direct arterial branches of the SHA or the IHA. This makes adenoma more susceptible to haemorrhage [7]. While uncommon, various other infections also have been reported to cause in pituitary apoplexy (Table 1). These include apoplexy caused by viral infection including Puumala [8], dengue [9], Hanta virus [10] and recently Covid-19 [11]. Tuberculosis and fungal infection associated with apoplexy have also been reported and these cases are treated with antitubercular or antifungal medication after surgery.Possible causative mechanisms that result in pituitary apoplexy in this scenario include thrombocytopenia and coagulation disorder or an autoimmune response leading to hemorrhagic vasculopathy.

With the available clinical information, we can only speculate as to the physiological mechanism that led to pituitary apoplexy, but we review various mechanisms that may result in this phenomenon. One of the proposed mechanisms of haemorrhage in leptospirosis is vasculopathy which mostly involves the capillaries. The postulated mechanism of this vascular insult is non-inflammatory vasculopathy. Disruption of endothelial cell-cell junctions, cell retraction and the consequent opening of intercellular gaps have been demonstrated by VE-cadherin immunohistochemistry [12]. Disruptions in adherens junctions due to protein alterations in VE-cadherins, p120 catenin, alpha and beta catenins has also been demonstrated [13]. This mechanism of increased permeability through cell junctions explains the occurrence of pulmonary oedema and haemorrhage in leptospirosis. Another postulated mechanism of cell surface injury in leptospirosis is the deposition of leptospiral antigen on the host cell membrane [3]. Tunjungputri et al. while investigating platelet dysfunction in leptospirosis, reported that increased VWF-platelet binding resulted in the activation and clearance of platelets leading to an increased severity of bleeding manifestations. Finally, platelet dysfunction may also be a result of uraemia, which occurs in the setting of acute kidney injury. Therefore, unlike many other viral infections like DHF, platelet dysfunction rather that an absolute decrease in platelet counts plays a greater role [14]. Hemorrhagic manifestations include epistaxis, hemoptysis, hematemesis, melena, conjunctival suffusion, skin rashes and other bleeding diatheses. Autopsy studies in have shown evidence of widespread hemorrhagic changes seen in the kidneys, liver, lungs, skeletal and cardiac muscles, serous membranes like the pleura and peritoneum and subarachnoid space $[15,16]$. Panidis et al. reported a case of leptospirosis causing hypogonadism and hypopituitarism, they proposed that this could be due to direct hypothalamic pituitary axis injury by the organism or may be secondary due to release of inflammatory substance [17].

The haemorrhage that occurs within the adenoma also resolves over a period of time, some of the possible mechanisms is presence of inflammatory reaction surrounding hemorrhage which causes resorption of the blood products [18]. 
Table 1 Various infectious causes associated with pituitary apoplexy reported in literature:

\begin{tabular}{|c|c|c|c|c|c|c|c|c|c|}
\hline References & Year & Age (years) & Sex & Diagnosis & $\begin{array}{l}\text { Management of } \\
\text { apoplexy }\end{array}$ & Outcome & $\begin{array}{l}\text { Follow up } \\
\text { imaging }\end{array}$ & $\begin{array}{l}\text { Follow up } \\
\text { (months) }\end{array}$ & Remarks \\
\hline $\begin{array}{r}\text { Arunkumar } \\
\text { et al. [21] }\end{array}$ & 2001 & 27 & M & $\begin{array}{l}\text { M. Tubercu- } \\
\text { losis }\end{array}$ & $\begin{array}{l}\text { Biopsy and } \\
\text { anti-tubercu- } \\
\text { lar medication }\end{array}$ & Improved & Reduced size & 9 & \\
\hline $\begin{array}{l}\text { Hautala et al. } \\
{[8]}\end{array}$ & 2002 & 58 & M & Puumala & NA & Death & NA & NA & $\begin{array}{l}\text { Pituitary necrosis } \\
\text { and hemor- } \\
\text { rhage. Puumala } \\
\text { virus pituitary } \\
\text { tissue positive } \\
\text { for Puumala } \\
\text { virus- } \mathrm{N} \text {-antigen }\end{array}$ \\
\hline $\begin{array}{l}\text { Hautala et al. } \\
\text { [8] }\end{array}$ & 2002 & 38 & M & Puumala & conservative & Recovered & Residual tumor & 10 & $\begin{array}{l}\text { Steroids and } \\
\text { thyroxine } \\
\text { replacement }\end{array}$ \\
\hline $\begin{array}{l}\text { Hautala et al. } \\
\text { [8] }\end{array}$ & 2002 & 19 & M & Puumala & conservative & Recovered & Residual tumor & 2 & $\begin{array}{l}\text { Steroids and } \\
\text { thyroxine } \\
\text { replacement }\end{array}$ \\
\hline $\begin{array}{l}\text { Cohen et al. } \\
\text { [22] }\end{array}$ & 2005 & 27 & F & $\begin{array}{l}\text { M. Tubercu- } \\
\text { losis }\end{array}$ & $\begin{array}{l}\text { Surgery and } \\
\text { antitubercular } \\
\text { medication }\end{array}$ & Improved & $\begin{array}{r}\text { Gross total } \\
\text { resection }\end{array}$ & 6 & \\
\hline $\begin{array}{l}\text { Salinas-Lara } \\
\text { et al. [23] }\end{array}$ & 2006 & 42 & $\mathrm{~F}$ & Mucormycosis & Surgery & Death & NA & NA & \\
\hline $\begin{array}{c}\text { Kumar et al. } \\
{[24]}\end{array}$ & 2011 & 31 & $\mathrm{~F}$ & Dengue & Surgery & $\begin{array}{l}\text { Improvement in } \\
\text { visual fields }\end{array}$ & NA & 3 & \\
\hline $\begin{array}{l}\text { Wildemberg } \\
\text { et al. [25] }\end{array}$ & 2012 & 40 & M & Dengue & Surgery & Improved & NA & 3 & \\
\hline $\begin{array}{l}\text { Wildemberg } \\
\text { et al. (25) }\end{array}$ & 2012 & 38 & M & Dengue & Surgery & Improved & NA & 2 & \\
\hline $\begin{array}{l}\text { Panigrahi et al. } \\
\text { [26] }\end{array}$ & 2014 & 43 & M & Dengue & Surgery & $\begin{array}{l}\text { Improvement in } \\
\text { visual fields }\end{array}$ & $\begin{array}{l}\text { Near-total } \\
\text { resection }\end{array}$ & 3 & \\
\hline $\begin{array}{l}\text { Seng Kiong } \\
\text { Tan et al. [9] }\end{array}$ & 2014 & 53 & M & Dengue & Surgery & $\begin{array}{l}\text { Residual vision } \\
\text { defect present } \\
\text { in the right } \\
\text { eye }\end{array}$ & $\begin{array}{l}\text { Residual pre- } \\
\text { sent }\end{array}$ & 3 & \\
\hline $\begin{array}{l}\text { Ayturk et al. } \\
{[10]}\end{array}$ & 2015 & 62 & M & Hantavirus & Surgery & Recovered & NA & 12 & \\
\hline $\begin{array}{l}\text { Kinberg et al. } \\
\text { [27] }\end{array}$ & 2018 & 67 & $\mathrm{~F}$ & Aspergillosis & Conservative & Recovered & $\begin{array}{l}\text { Residual tumor } \\
\text { in the cavern- } \\
\text { ous sinus }\end{array}$ & 6 & $\begin{array}{l}\text { Amp B and vari- } \\
\text { conazole for } \\
\text { aspergillosis }\end{array}$ \\
\hline $\begin{array}{l}\text { Pineda et al. } \\
\text { [28] }\end{array}$ & 2020 & 27 & M & SARS-CoV-2 & Conservative & Death & NA & NA & $\begin{array}{l}\text { Pulmonary com- } \\
\text { plications }\end{array}$ \\
\hline Chan et al. [11] & 2020 & 28 & $\mathrm{~F}$ & SARS-CoV-2 & Surgery & Improved & NA & NA & $\begin{array}{l}\text { Full-term } \\
\text { delivery prior } \\
\text { to pituitary } \\
\text { surgery }\end{array}$ \\
\hline $\begin{array}{l}\text { Catarino et al. } \\
\text { [29] }\end{array}$ & 2020 & 55 & $\mathrm{~F}$ & $\begin{array}{l}\text { Septate fungal } \\
\text { infection } \\
\text { (species not } \\
\text { described) }\end{array}$ & $\begin{array}{l}\text { Surgery and } \\
\text { antifungal } \\
\text { medication }\end{array}$ & $\begin{array}{l}\text { Improved clini- } \\
\text { cally }\end{array}$ & $\begin{array}{r}\text { Gross total } \\
\text { resection }\end{array}$ & 4 & \\
\hline
\end{tabular}

The time for resolution of pituitary apoplexy ranges from 6 week to 3 month [19]. Jackson et al. described $40 \%$ reduction in size at end of 1 week and $67.6 \%$ reduction at end of 7 weeks [20]. In our case it showed near complete resolution at 1 month.

\section{Conclusion}

Leptospirosis is a common tropical febrile illness that may manifest with the hepatorenal syndrome and systemic hemorrhagic manifestations. Leptospirosis leads to a non-inflammatory vasculopathy affecting capillaries 
disrupting endothelial cell-cell junctions. Very rarely, in a patient harboring a pituitary adenoma this vasculopathy may result in pituitary apoplexy.

\section{References}

1. Faine S, Adler B, Bolin C, Perolat P (1999) "Leptospira" and leptospirosis. MediSci, Melbourne Vic Australia, p 295

2. Adler B, de la Peña MA (2010) Leptospira and leptospirosis. Vet Microbiol 140(3-4):287-296

3. Haake DA, Levett PN (2015) Leptospirosis in humans. Curr Top Microbiol Immunol 387:65-97. https://doi.org/10.1007/ 978-3-662-45059-8_5

4. Arean VM (1962) The pathologic anatomy and pathogenesis of fatal human leptospirosis (weil's disease). Am J Pathol 40(4):393-423

5. Fulara SN, Fulara NY (2016) Weil's disease (fulminating leptospirosis) complicating as acute respiratory distress syndrome. Open J Clin Diagn 06(03): 19-24

6. Bhatt M, Rastogi N, Soneja M et al (2018) Uncommon manifestation of leptospirosis: a diagnostic challenge. Case Reports 2018:bcr2018225281

7. Briet C, Salenave S, Bonneville J-F, Laws ER, Chanson P (2015) Pituitary apoplexy. Endocr Rev 36(6):622-645

8. Hautala T, Sironen T, Vapalahti O, Pääkkö E, Särkioja T, Salmela PI et al (2002) Hypophyseal hemorrhage and panhypopituitarism during puumala virus Infection: magnetic resonance imaging and detection of viral antigen in the hypophysis. Clin Infect Dis Off Publ Infect Dis Soc Am 35(1):96-101

9. Tan SK, Seow CJ, Tan E, Chau YP, Dalan R (2014) Pituitary apoplexy secondary to thrombocytopenia due to dengue hemorrhagic fever: a case report and review of the literature. Endocr Pract 20(4):e58-64. https://doi.org/10.4158/EP13319.CR

10. Ayturk S, Genc A, Yaylaci S, Karabay O, Tamer A, Celik M (2015) Pituitary apoplexy case caused by Hanta virus infection. Endocr Abstr. https://doi.org/10.1530/endoabs.37.EP1160

11. Chan JL, Gregory KD, Smithson SS et al (2020) Pituitary apoplexy associated with acute COVID-19 infection and pregnancy. Pituitary 23:716-720

12. Croda J, Neto AND, Brasil RA, Pagliari C, Nicodemo AC, Duarte MIS (2010) Leptospirosis pulmonary haemorrhage syndrome is associated with linear deposition of immunoglobulin and complement on the alveolar surface. Clin Microbiol Infect 16(6):593-599

13. Sato H, Coburn J (2017) Leptospira interrogans causes quantitative and morphological disturbances in adherens junctions and other biological groups of proteins in human endothelial cells. PLoS Negl Trop Dis 11(7):e0005830. https://doi.org/10.1371/ journal.pntd.0005830

14. Tunjungputri RN, Gasem MH, van der Does W et al (2017) Platelet dysfunction contributes to bleeding complications in patients with probable leptospirosis. PLoS Negl Trop Dis 11(9):5915

15. Wagenaar JF, Goris MG, Partiningrum DL, Isbandrio B, Hartskeerl RA, Brandjes DP, Meijers JC, Gasem MH, van Gorp EC
(2010) Coagulation disorders in patients with severe leptospirosis are associated with severe bleeding and mortality. Trop Med Int Health 15(2):152-159. https://doi.org/10.1111/j.1365-3156.2009. 02434.x

16. Salkade HP (2005) A study of sutopsy findings in cases of leptospirosis in a metropolitan city in India. J Postgrad Med 51(3):5

17. Panidis D, Rousso D, Skiadopoulos S, Vavilis D, Kalogeropoulos A (1994) Hypothalamic-pituitary deficiency after Weil's syndrome: a case report. Fertil Steril 62(5):1077-1079

18. Liu S, Wang X, Liu YH, Mao Q (2012) Spontaneous disappearance of the pituitary macroadenoma after apoplexy: a case report and review of the literature. Neurol India 60(5):530-532. https:// doi.org/10.4103/0028-3886.103211

19. Kachhara R, Nair S, Gupta AK (2000) Spontaneous resolution of a non- functioning pituitary adenoma following an apoplexy. Neurol India 48:294

20. Jackson DL, Van Gompel JJ (2015) Rapid pituitary apoplexy regression: what is the time course of clot resolution. Case Rep Radiol 2015:1-5

21. Arunkumar MJ, Rajshekhar V (2001) Intrasellar tuberculoma presenting as pituitary apoplexy. Neurol India 49:407-410

22. Deogaonkar M, De R, Sil K, Das S (2006) Pituitary tuberculosis presenting as pituitary apoplexy. Int J Infect Dis 10(4):338-339

23. Salinas-Lara C, Rembao-Bojórquez D, de la Cruz E, Márquez C, Portocarrero L, Tena-Suck ML (2008) Pituitary apoplexy due to mucormycosis infection in a patient with an ACTH producing pulmonary tumor. J Clin Neurosci 15(1):67-70

24. Agarwal V, Kataria R, Mehta V (2011) Dengue hemorrhagic fever: a rare cause of pituitary tumor hemorrhage and reversible vision loss. Indian J Ophthalmol 1(59):311-312

25. Wildemberg LEA, Neto LV, Niemeyer P, Gasparetto EL, Chimelli L, Gadelha MR (2012) Association of dengue hemorrhagic fever with multiple risk factors for pituitary apoplexy. Endocr Pract 18(5):97-101

26. Mishra SS, Panigrahi S, Das S (2014) Dengue hemorrhagic fever: a rare cause of pituitary apoplexy. Neurol India 62(1):92-93

27. Kinberg E, Pacheco C, Stepan K et al (2018) Pituitary aspergillosis presenting as macroadenoma: case report and review of literature. J Otolaryngol ENT Res 10(2):110-112. https://doi.org/ 10.15406/joentr.2018.10.00324

28. Solorio-Pineda S, Almendárez-Sánchez CA, Tafur-Grandett AA, Ramos-Martínez GA, Huato-Reyes R, Ruiz-Flores MI, SosaNajera A (2020) Pituitary macroadenoma apoplexy in a severe acute respiratory syndrome-coronavirus-2-positive testing: causal or casual? Surg Neurol Int 25(11):304. https://doi.org/10.25259/ SNI_305_2020

29. Catarino D, Ribeiro C, Gomes L, Paiva I (2020) Corticotroph adenoma and pituitary fungal infection: a rare association. Endocrinol Diabetes Metab Case Rep 25:2020

Publisher's Note Springer Nature remains neutral with regard to jurisdictional claims in published maps and institutional affiliations. 